\title{
RAGWEED (Ambrosia L.) POLLEN IN AEROPLANKTON OF LUBLIN (POLAND) AND LVIV (UKRAINE)
}

\author{
Krystyna Piotrowska-Weryszko ${ }^{1}$, Elżbieta Weryszko-Chmielewska ${ }^{2}$, \\ Kateryna Voloshchuk ${ }^{3}$, Aneta Sulborska ${ }^{2}$, Nataliya Kalinovych ${ }^{3}$, Nataliya Vorobets ${ }^{4}$ \\ ${ }^{1}$ Department of General Ecology, University of Life Sciences in Lublin, Akademicka 15, 20-950 Lublin, Poland \\ ${ }^{2}$ Department of Botany, University of Life Sciences in Lublin, Akademicka 15, 20-950 Lublin, Poland \\ ${ }^{3}$ Department of Botany, Ivan Franko National University of Lviv, 4, Hrushevsky St., Lviv 79005, Ukraine \\ ${ }^{4}$ Danylo Halytsky Lviv National University, 79010 Lviv, Ukraine \\ e-mail: krystyna.piotrowska@up.lublin.pl
}

Received: 15.03.2013

\begin{abstract}
In Europe Ambrosia is included in invasive species. Its pollen contains very strong allergens that can be the cause of pollinosis at the turn of summer and autumn. The aim of the present study was to compare Ambrosia pollen concentrations in the air of Lublin and Lviv and to analyse the effect of weather conditions on Ambrosia pollen content in the air. The study was carried out in 2011 and 2012. In Lublin the volumetric method was applied using a Lanzoni VPPS 2000 trap, whereas in Lviv the gravimetric method was applied using a Durham trap. To make the results comparable, the data obtained by the gravimetric method were properly counted and expressed as the number of pollen grains per $1 \mathrm{~m}^{3}$ of air. This research shows that the Ambrosia pollen season started about a month earlier in Lviv and lasted longer than in Lublin. In Lviv ragweed pollen was recorded from the beginning of July, while in Lublin from the second week of August. The pollen season in both cities ended on different days of October. The seasonal peaks in both years and the annual pollen count in 2011 were much higher in Lublin than in Lviv. In both cities air temperature was the most important meteorological factor affecting pollen concentrations. During the pollen season in Lublin, the wind was predominantly from $\mathrm{NE}$ and $\mathrm{E}$ directions, whereas in Lviv from $\mathrm{N}$ and $\mathrm{SE}$.
\end{abstract}

Key words: aerobiology, Ambrosia, pollen season, meteorological factors, Poland, Ukraine, 2011-2012

\section{INTRODUCTION}

The genus Ambrosia L. (Asteraceae) includes 40 species originally native to North America where it is a frequent cause of pollen allergy [1,2]. Several spe- cies of the genus Ambrosia, whose seeds were brought from America with grain shipments, have spread across many countries of Europe. Among them, the following are the most frequently found: A. artemisiifolia L., A. psilostachya DC., and A. tryfida L. [3,4,5,6].

In Poland $A$. artemisiifolia L. and A. psilostachya DC are most often recorded. Their locations are dispersed in different parts of the country $[7,8]$. In Ukraine A. artemisiifolia L., A. trifida L. and A. aptera DC. are observed [9]. Species of the genus Ambrosia are annual or perennial anemophilous plants. In Europe they are classified as invasive species [10]. In Ukraine and Poland Ambrosia is included in the list of quarantine pest plants, in the latter country under the Regulation of the Ministry of Agriculture and Food Economy of 6 February 1996 regarding the control of pest organisms [11].

In Europe an increasing number of Ambrosia locations are recorded and this may result from climate changes and the existence of many areas that promote the growth of these plants $[3,11,12]$. The increasing pollen concentrations of this taxon in aeroplankton are a real threat to allergy sufferers.

The aim of this study was to compare the pattern of daily Ambrosia pollen concentrations in Lublin and Lviv over a period of 2 years and to analyse the correlations between pollen concentration and selected meteorological factors. No ragweed sites were found in Lublin and in its vicinity, whereas in Lviv concentrations of these plants are quite numerous, particularly along railway tracks and in untidy lawns. 


\section{MATERIALS AND METHODS}

During the period of 2011 and 2012, monitoring of airborne Ambrosia pollen was carried out in two cities: Lublin (Poland) and Lviv (Ukraine). The distance between these two study sites is about $200 \mathrm{~km}$. In Lublin the volumetric method was applied using a Hirst-type sampler (Lanzoni VPPS 2000) which was placed at a height of $18 \mathrm{~m}$ on the roof of the building of the University of Life Sciences in the city centre $\left(51^{\circ} 14^{\prime} 37^{\prime} ' \mathrm{~N} ; 2^{\circ} 32^{\prime} 25^{\prime \prime} \mathrm{E}\right)$. The research methodology followed the recommendations of the International Association for Aerobiology [13]. Pollen was counted on slides along 4 longitudinal transects with a length of $48 \mathrm{~mm}$ each.

In Lviv the gravimetric method was applied using a Durham trap which was placed at a height of $10 \mathrm{~m}$ in the city centre (49 $\left.50^{\prime} 8^{\prime \prime} \mathrm{N} ; 2^{\circ} 1^{\prime} 58^{\prime \prime} \mathrm{E}\right)$. Pollen grains were counted on the entire slide and the total slide area was $11.52 \mathrm{~cm}^{2}$. To determine airborne ragweed pollen concentrations, the data obtained by the gravimetric method were converted using a factor of 3.2 which was calculated following the guidelines of Basett et al. [14]. Similarly as in the case of Lublin, the obtained results were expressed as the number of pollen grains per $1 \mathrm{~m}^{3}$ of air in 24 hours $\left(\mathrm{P} / \mathrm{m}^{3}\right)$.

The correlations between pollen concentration and meteorological factors were analysed for both cities. The following weather data were included in the analysis: temperature (mean, minimum, maximum), air humidity, wind direction. In Lublin the meteorological data were obtained from an automatic weather station Vantage Pro 2 located close to the pollen trap, while in Lviv from the website www.meteoprog.ua/ ua/fwarchive/Lviv/. The correlations between airborne pollen concentration and meteorological factors were calculated by Spearman's rank correlation test. STATISTICA ver. 8 and GraphPad Prism 5 software was used for the statistical analysis.

\section{RESULTS}

Specimens of Ambrosia artemisiifolia and their inflorescences as well as pollen grains were observed in Lviv (Figs 1-8). The studies show that the Ambrosia pollen season started about a month earlier in Lviv than in Lublin (Figs 9,10). In 2011 and 2012 years ragweed pollen was present in aeroplankton of Lviv from the beginning of July, while in Lublin from the second week of August. In both cities the end of the ragweed pollen season was recorded in the second (2012) or third (2011) 10-day period of October. During two years of the study, this date was later in $\mathrm{Lu}-$ blin than in Lviv, on average by 6 days. All the seasons analysed were right-skewed; the coefficient of skewness in Lublin ranged 3.8-4.1 and in Lviv 2.6-3.3. In 2011 the highest ragweed pollen concentrations were recorded on the same day (27 August) at both sites, whereas in 2012 the seasonal peak in Lublin was on 12 September, but in Lviv high concentrations with a similar value were observed on several dates (19 July, 22 and 26 August, 12 September).

In both years the maximum pollen concentrations were much higher in Lublin than in Lviv (Fig. $11)$. On the other hand, the annual pollen counts showed different relations. In 2011 twice more pollen was recorded in Lublin than in Lviv, while in 2012 these values were similar in both cities (Fig. 12). The analysis of the pattern of the ragweed pollen seasons in Lublin and Lviv reveals that the pollen concentrations showed either an increasing trend or a decreasing trend over the same period. In both years of the study, the pollen season both in Lublin and in Lviv was characterized by the lack of continuity. Days with the ragweed pollen content in the air were alternated with days on which there was no airborne ragweed pollen.

The analysis of Spearman's rank correlations revealed that air temperature was the most important meteorological factor affecting daily ragweed pollen concentrations (Table 1). Lviv was shown to have the highest correlation between pollen concentration and air temperature, whereas for Lublin the correlation coefficients for particular temperatures were at a similar level. Air humidity was also found to have a significant effect on ragweed pollen concentration in Lviv. In Lublin this correlation was not statistically significant.

Table 1

Spearman's correlation coefficients between ragweed pollen concentration and selected meteorological factors for Lublin and Lviv (total for 2011-2012)

\begin{tabular}{ccccc}
\hline \multirow{2}{*}{ Site } & \multicolumn{3}{c}{ Temperature } & Humidity \\
\cline { 2 - 4 } & mean & minimum & maximum & \\
\hline Lublin & $0.271^{* *}$ & $0.273^{* *}$ & $0.272^{* *}$ & -0.125 \\
Lviv & $0.395^{* *}$ & $0.258^{* *}$ & $0.445^{* *}$ & $-0.292^{* *}$ \\
\hline$* * \mathrm{p}<0.01$ & & & &
\end{tabular}



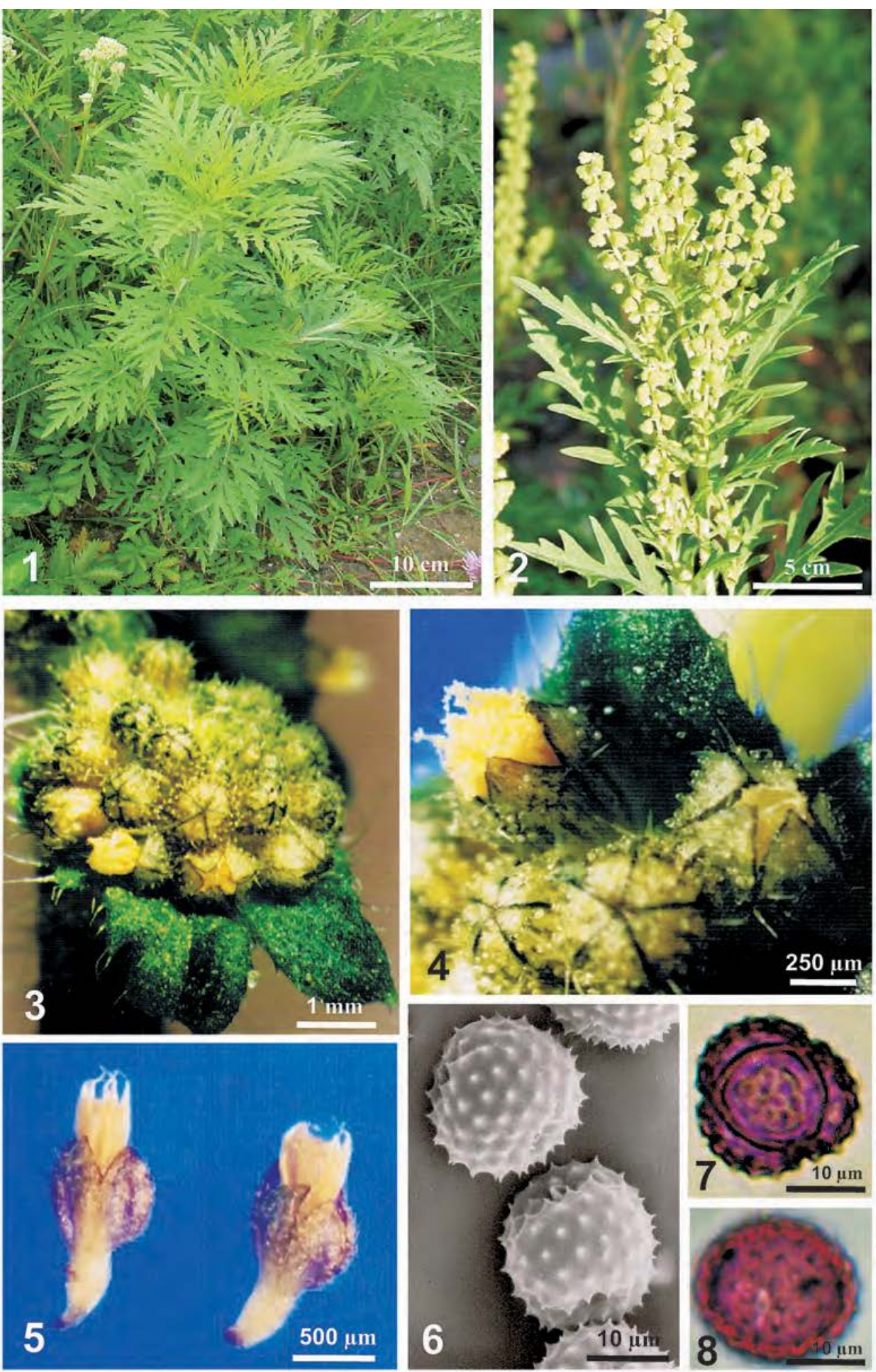

Fig. 1. Specimens of Ambrosia artemisiifolia growing in residential area of Lviv.

Fig. 2. Upper parts of an A. artemisiifolia plant with inflorescences.

Fig. 3. Anthodium with male flowers at the start of flowering.

Fig. 4. Opening male flowers in the anthodium.

Fig. 5. Two male flowers dissected from the anthodium.

Fig. 6. A. artemisiifolia pollen grains (SEM).

Fig. 7. Pollen grain in polar view (LM).

Fig. 8. Pollen grain in equatorial view (LM). 


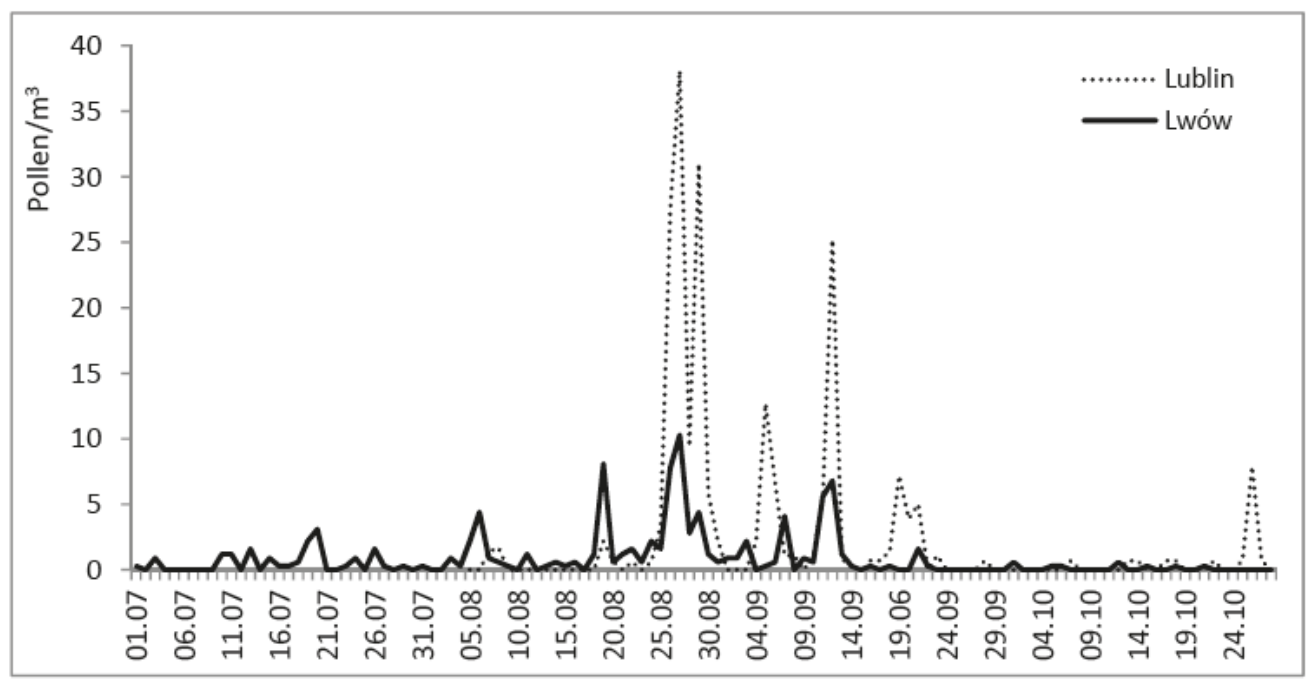

Fig. 9. Comparison of Ambrosia pollen concentrations in the air of Lublin and Lviv in 2011.

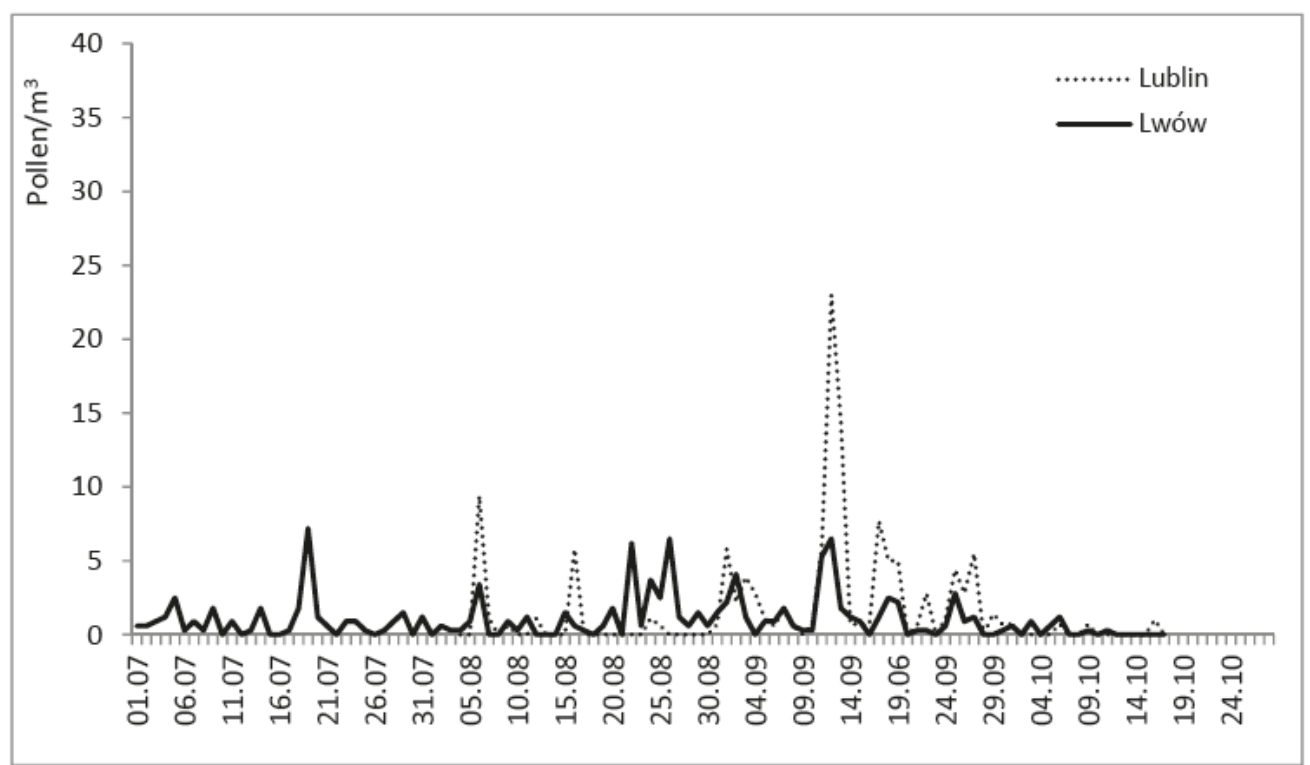

Fig. 10. Comparison of Ambrosia pollen concentrations in the air of Lublin and Lviv in 2012.

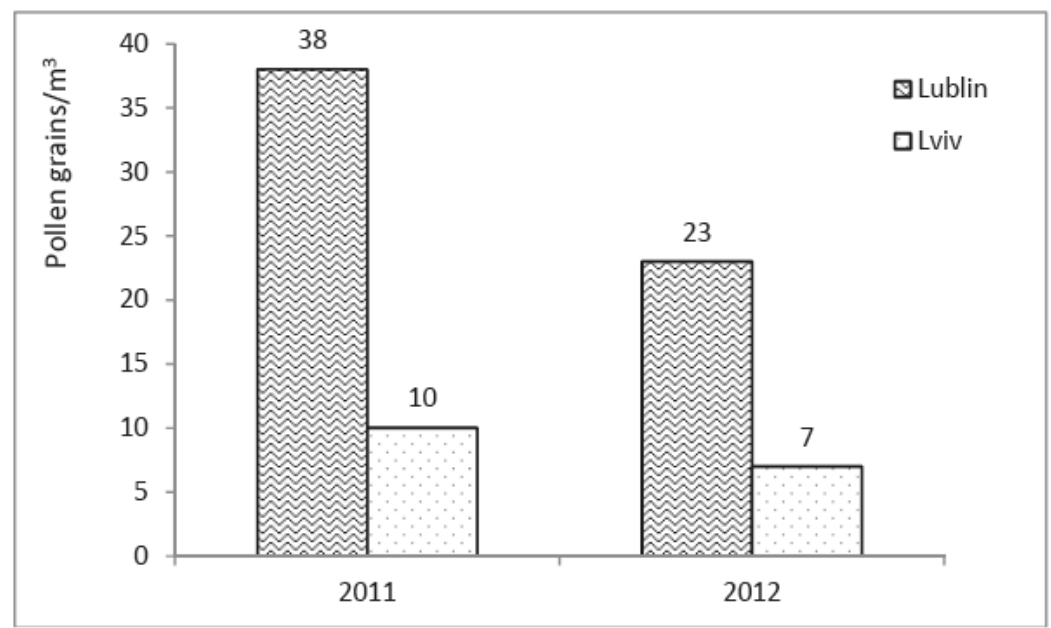

Fig. 11. Comparison of maximum pollen concentrations of Ambrosia in Lublin and Lviv, 2011-2012. 


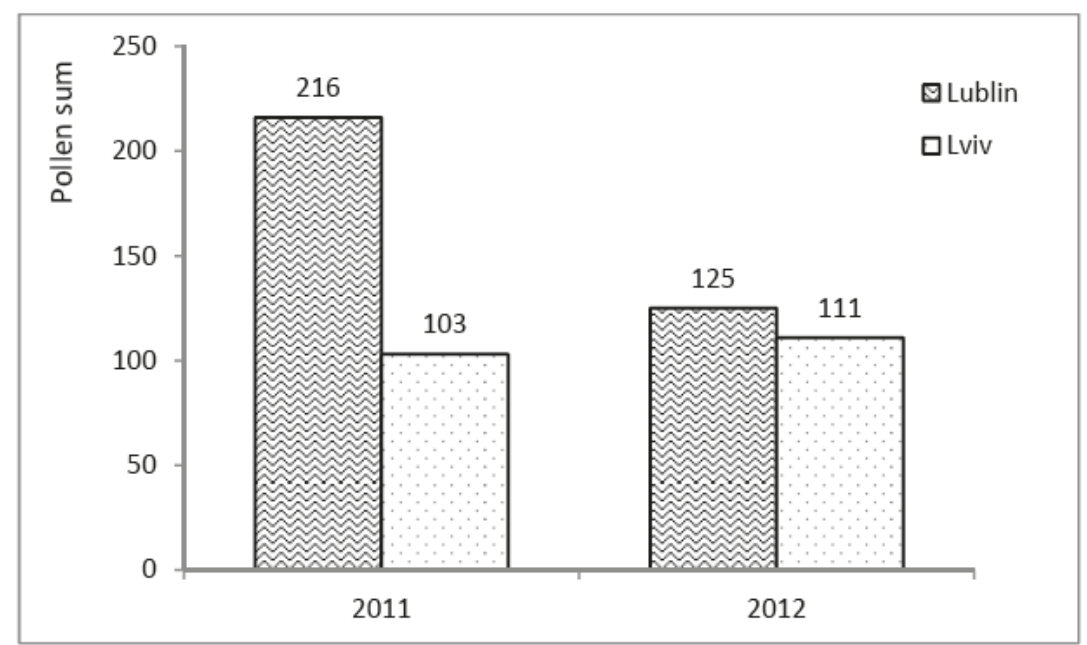

Fig. 12. Annual pollen index in Lublin and Lviv, 2011-2012.

Ragweed pollen is characterized by high floating capacity and can be carried for long distances; therefore; in this study special attention was paid to the directions of winds that occurred during the pollen season. The wind direction analysis included the data for days on which ragweed pollen grains were recorded as well as the data from the previous day if there was an interruption in the continuity of the season. In 2011 in Lublin the predominant wind direction was from $\mathrm{E}(26.9 \%)$ and winds from $\mathrm{NE}$ and $\mathrm{W}$ directions were also recorded frequently $(22.2 \%$ each), whereas the wind direction frequency was the lowest for winds from $\mathrm{N}$ and $\mathrm{S}$ ( $4.6 \%$ each). In 2012 the wind from NE direction was by far the most frequent $(33.7 \%$ ) during the study period, followed by winds from $\mathrm{N}$ and $\mathrm{E}$ directions (12.2\% each), while the wind from $\mathrm{S}$ was the least frequent wind direction $(2.0 \%)$. The wind rose which includes the mean

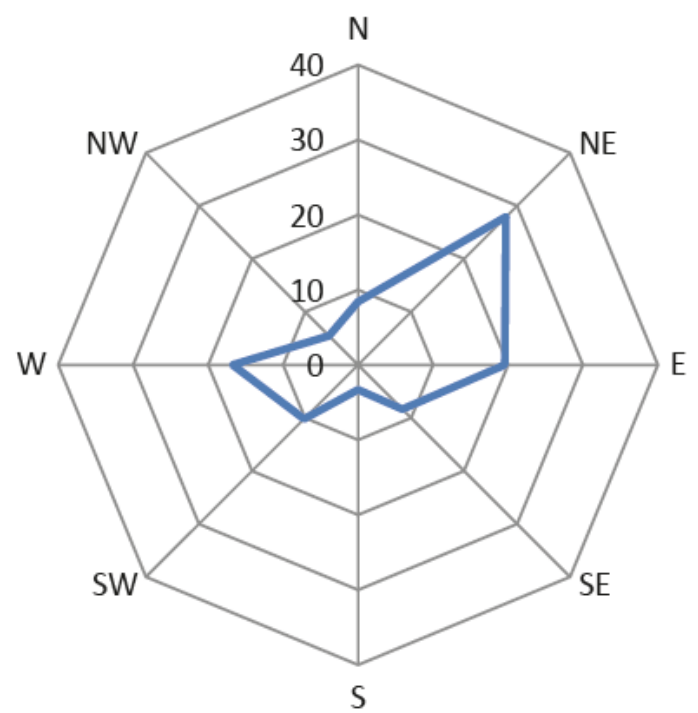

Fig. 13. The frequency of wind directions during the Ambrosia pollen season in Lublin (mean for 2011 and 2012). data for Lublin for the years 2011 and 2012 shows that winds from $\mathrm{NE}$ and $\mathrm{E}$ had the greatest direction frequency, while the wind from $\mathrm{S}$ direction had the lowest frequency (Fig. 13). On the other hand, on days of high pollen concentration winds from $\mathrm{W}(41.7 \%)$ and SW (25.0\%) directions prevailed. In 2011 in Lviv the wind from $\mathrm{N}(52.8 \%)$ and SE (18.0\%) showed the greatest frequency of wind direction, while in 2012 from SE (28.0\%) and $\mathrm{W}(18.3 \%)$ directions. The wind from NE (2011) and S (2012) directions was the least frequent. On the basis of the mean data for both years of the study, it was found that in Lviv winds from N (35.0\%) and SE $(24.1 \%)$ directions were the most frequent during the ragweed pollen season, while the least frequent wind directions were from $\mathrm{S}(1.7 \%)$ and $\mathrm{E}(2.2 \%)$ (Fig. 14). On days of high pollen concentration, winds from $\mathrm{N}$ and $\mathrm{SE}$ directions were mostly recorded ( $42.9 \%$ each).

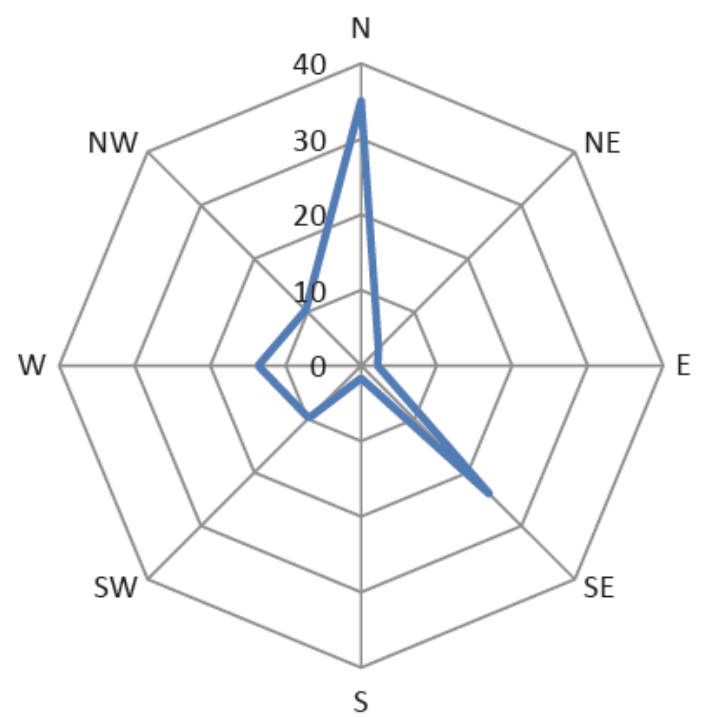

Fig. 14. The frequency of wind directions during the Ambrosia pollen season in Lviv (mean for 2011 and 2012). 


\section{DISCUSSION}

The results relating to Ambrosia pollen content in the air of Lublin and Lviv, presented in this paper, show a much lower amount of pollen in Lviv than in Lublin. These differences can result from the application of different methods and the use of the conversion factor. The obtained data does not fully reflect the existing situation, since in Lviv, contrary to Lublin, concentrations of A. artemisiifolia plants are recorded in different parts of the city.

The research conducted in the period 20012005 in different regions of Poland demonstrates that the largest amounts of Ambrosia pollen were noted in Lublin, despite the fact that within a radius of 50 $\mathrm{km}$ from the city no representatives of this genus were found. Information can be found in the literature that species of the genus Ambrosia have been recorded in Szczecin [15], in the area of Wrocław [16], Lower Silesia [17] as well as near Kraków and Rzeszów [7]. However, a comparison of the mean annual pollen counts for the period 2001-2005 reveals that there was much less pollen of this taxon in the above-mentioned cities than in Lublin: in Szczecin $196 \mathrm{P} / \mathrm{m}^{3}$, in Wrocław $264 \mathrm{P} / \mathrm{m}^{3}$, in Kraków $179 \mathrm{P} / \mathrm{m}^{3}$, and in Rzeszów 322 P/ $\mathrm{m}^{3}$, while in Lublin it was $602 \mathrm{P} / \mathrm{m}^{3}$. During the above-mentioned period, the maximum daily Ambrosia pollen concentration was also the highest in Lublin (176 $\mathrm{P} / \mathrm{m}^{3}$ ), whereas the respective values of this parameter for the other cities were as follows: Wrocław $91 \mathrm{P} /$ $\mathrm{m}^{3}$, Rzeszów $70 \mathrm{P} / \mathrm{m}^{3}$, Szczecin $52 \mathrm{P} / \mathrm{m}^{3}$, and Kraków $27 \mathrm{P} / \mathrm{m}^{3}$ [18]. In the next years, the total annual pollen counts and daily Ambrosia pollen concentrations in Lublin decreased. The mean annual pollen count for 2009-2012 was $206 \mathrm{P} / \mathrm{m}^{3}$, while the maximum daily concentration $57 \mathrm{P} / \mathrm{m}^{3}$ [19].

Our earlier study conducted in Lublin and Lviv [20] and the present research demonstrate that the ragweed pollen season starts much earlier and lasts longer in Lviv than in Lublin. This may result from the differences in the geographic location of both cities as well as from the fact that in Lviv southeasterly winds are frequently recorded and they can bring pollen from distant areas where the growing season lasts longer and plants release more pollen. The literature data show that maximum daily ragweed pollen concentrations in Zaporizhia, located to the south-east of Lviv, reach very high values of $1950 \mathrm{P} / \mathrm{m}^{3}$ [11]. We found in our study that there was a high correlation between temperature and Ambrosia pollen content in the air. Similar results relating to the correlation between Ambrosia pollen concentration and temperature have been obtained by $\mathrm{S}$ tę pa ls k a et al. [21], $\mathrm{P} \mathrm{u} \mathrm{c} \mathrm{[22],}$ and $\mathrm{K}$ a s przyk [23].

The determined trend lines for Ambrosia pollen in aeroplankton of Lublin reveal clear declining trends in Ambrosia pollen counts over the last 12 lat (20012012) [19]. Because Ambrosia species are controlled as invasive plants, this fact perhaps contributes to the decrease in the number of pollen grains of this pollen in the air of Lublin.

Our research shows that during the analysed Ambrosia pollen seasons in Lublin $(2011,2012)$ northeasterly and easterly winds prevailed, whereas on days of maximum pollen concentration and on the preceding days westerly and southwesterly winds were dominant. It seems therefore that pollen of plants of the genus Ambrosia can be carried to Lublin by long-range transport (more than $100 \mathrm{~km}$ ) both from Ukraine and its neighbouring countries, and also from those situated beyond the southern Polish border. Using a back-trajectory analysis in 2005, it was demonstrated that the Ambrosia pollen recorded in Lublin could have originated from Hungary or Slovakia [24]. Based on a similar analysis conducted in Poznań, it was found that ragweed pollen grains recorded in this city could have come from southern Poland, Slovakia, the Czech Republic, or Hungary [25].

\section{CONCLUSIONS}

1. The present research demonstrates that the higher Ambrosia pollen concentrations in aeroplankton of Lublin can be evidence of intensive long-range transport from behind the eastern and southern border of Poland, since no ragweed sites were found in the area of Lublin.

2. In Lviv much longer Ambrosia pollen seasons were recorded than in Lublin, which may result from geographic location of these cities.

\section{Acknowledgements}

Research supported by Poland's Ministry of Science and Higher Education as part of the statutory activities of the Department of Botany and General Ecology, University of Life Sciences in Lublin.

\section{Authors' contributions:}

Concept of the study: EW-C; microscopial analysis: EW-C, KP-W, AS, KV, NK, NV; photographs: EW-C, KP-W, AS; statistical analysis KP-W, KV; analysis of research results: KP-W; writing of the manuscript: KP-W, EW-C, AS.

\section{REFERENCE}

1. Bousquet J., van Cauwenberge P., Khaltaev N. Aria Worshop Group; World Health Organization: Allergic rhintis and its impact on asthma. J. Allergy Clin. Immunol. 2001; 108(5 supl.): 147-334. 
2. Peternel R., Čulig J., Hrga I, Hercog P. Airborne ragweed (Ambrosia artemisiifolia L.) pollen concentrations in Croatia, 2002-2004. Aerobiologia. 2006; 22: 161-168. http://dx.doi.org/10.1007/s10453-006-9028-9

3. Jäger S . Allergenic significance of Ambrosia (ragweed). [In:] G. D’Amato, F. Th. M. Spieksma, S. Bonini (eds), Allergenic pollen and pollinosis in Europe. Oxford: Blackwell Sci. Publ.; 1991; 125-127.

4. Jäger S. Ragweed (Ambrosia) sensitisation rates correlate with the amount of inhaled airborne pollen. A 14-year study in Vienna, Austria. Aerobiologia. 2000; 16: 149-153. http:// dx.doi.org/10.1023/A:1007603321556

5. Jarai-Komlodi M. Some details about ragweed airborne pollen in Hungary. Aerobiologia. 2000; 16(2): 291294.

6. Rybnicek O., Jäger S. Ambrosia (Ragweed) in Europe. ACI International. 2001; 13(2): 60-66.

7. Zając A., Zając M. (Eds): Atlas rozmieszczenia roślin naczyniowych w Polsce. Kraków: Wyd. Instytutu Botaniki UJ; 2001. (in Polish)

8. Weryszko-Chmielewska E., Piotrowska K. Ecological features of Ambrosia artemisiifolia L. flowers and characteristics of Ambrosia L. pollen season in the condition of Lublin (Poland) in the years 2001-2008. Acta Agrobot. 2008; 61(2): 35-47. http://dx.doi.org/10. 5586\%2Faa.2008.031

9. Makhovska L.J., Fedoljak M.A., Fedol$\mathrm{jak}$ V.A. The spreading of Ambrosia artemisiifolia L. (Asteraceae) on the territory of Ivano-Frankivsk and its suburbs. Newsletter Precarpathian national University named after Vasyl Stefanyk. Herald. Biology. - IvanoFrankivsk: Play, 2009. - Part XIII. - 151 p.

10. Taramarcaz P., Lambelet C., Clot B., Keimer C., Hauser C. Ragweed (Ambrosia) progression and it's health risks: will Switzerland resist this invasion? Swiss Med Wkly. 2005; 135: 538-548. http://dx.doi. org/10/2005; 135(37-38):538-48

11. Ra piejko P. Alergeny pyłku roślin. Warszawa: Medical Education; 2008. (in Polish)

12. Fernández-Llamazares A., Belmonte J., Alarcón M., López-Pacheco M. Ambrosia L. in Catalonia (NE Spain): expansion and aerobiology of a new bioinvader. Aerobiologia. 2012; 28: 435-451. http://dx.doi. org/10.1007/s10453-012-9247-1

13. Mandrioli P., Comtois P., Dominguez Vilches E., Galan Soldevilla C., Syzdek L., I s a rd S. Sampling: principles and techniques. In: P. Mandrioli, P. Comtois, V. Levizzani (Eds), Methods in aerobiology. Bologna: Pitagora Editrice: 47-112; 1998.

14. Bassett J., Crompton C.W., Parmelee J.A. An atlas airborne pollen grains and common fungus spores of Canada. Ottawa, Ontario: Biosystematics Research Institute; 1978.

15. P u c M. Ragweed pollen in the air of Szczecin. Ann. Agric. Environ. Med. 2004; 11(1): 53-7.

16. Malkiewicz M., Balwierz Z., Chłopek K., Myszkowska D., Weryszko-Chmielewska E.,
Piotrowska K., Uruska A., Modrzyński M., Tarasewicz A., Lipiec A. Analiza stężenia pyłku ambrozji w wybranych miastach Polski w 2005 r. / Analysis of ragweed pollen count in selected Polish cities in 2005. Alergoprofil 2005; 2: 55-59. (in Polish)

17. Chłopek K., Tokarska-Guzik B. Pyłek ambrozji (Ambrosia) w aeroplanktonie Górnego Śląska. I Ragweed (Ambrosia) pollen in aeroplankton of Upper Silesia. Acta Agrobot. 2006; 59(1): 335-345. http://dx.doi. org/10.5586\%2Faa.2006.035 (in Polish)

18. Weryszko-Chmielewska E. (Ed). Pyłek roślin w aeroplanktonie różnych regionów Polski. Lublin: Wyd. Akademii Medycznej; 2006. (in Polish)

19. Piotrowska-Weryszko K. Dynamika sezonów pyłkowych ambrozji w Lublinie i ryzyko występowania alergii pyłkowej. / Dynamics of ragweed pollen season in Lublin and risk of pollen allergy. Alergoprofil. 2012; 8(4): 24-30. (in Polish)

20. Weryszko-Chmielewska E., Piotrowska K., Czernećkyj M. Pyłek ambrozji (Ambrosia) i iwy (Iva) w powietrzu Lublina i Lwowa. / Ambrosia and Iva pollen in the air of Lublin and Lviv. Ann. Univ. Mariae Curie-Skłodowska, Sect. EEE. 2003; XIII: 341-348. (in Polish)

21. Stępalska D., Szczepanek K., Myszkowska D. Variation in Ambrosia pollen concentration in Southern and Central Poland in 1982-1999. Aerobiologia. 2002; 18: 13-22.

22. P u c M. Ragweed and mugwort pollen in Szczecin, Poland. Aerobiologia. 2006; 22: 67-78. http://dx.doi.org/10.1007/ s10453-005-9010-y

23. K a s pr z y k I. Non-native Ambrosia pollen in atmosphere of Rzeszów (SE Poland); evaluation of the effect of weather conditions on daily concentrations and starting dates of the pollen season. Int. J. Biometeorol. 2008; 52: 341-351. http://dx.doi.org/10.1007/s00484-007-0129-0

24. Smith M., Skjřth C.A., Myszkowska D., Uruska A., Puc M., Stach A., Balwierz Z., Chłopek K., Piotrowska K., Kasprzyk I., $\mathrm{B}$ r a n d t J. Long-range transport of Ambrosia pollen to Poland. Agricultural and Forest Meteorology. 2008; 148: 14021411. http://dx.doi.org/10.1016/j.agrformet.2008.04.005

25. Stach A., Smith M., Skjřth C.A., Brandt J . Examining Ambrosia pollen episodes at Poznań (Poland) using back-trajectory analysis. Int. J. Biometeorol. 2007; 51: 275-286. http://dx.doi.org/10.1007/s00484-006-0068-1

\section{Pyłek ambrozji (Ambrosia L.) w aeroplanktonie Lublina (Polska) i Lwowa (Ukraina)}

\section{Streszczenie}

Ambrosia zaliczana jest w Europie do gatunków inwazyjnych. Jej pyłek zawiera bardzo silne alergeny, które mogą być przyczyną pyłkowicy na przełomie lata i jesieni. Celem pracy było porównanie 
stężenia pyłku Ambrosia w powietrzu Lublina i Lwowa oraz analiza wpływu warunków pogodowych na zawartość pyłku w atmosferze. Badania prowadzono w latach 2011 i 2012. W Lublinie zastosowano metodę wolumetryczną z wykorzystaniem aparatu Lanzoni VPPS 2000, natomiast we Lwowie posłużono się metodą grawimetryczną z użyciem aparatu Durhama. Aby wyniki były porównywalne, dane uzyskane metodą grawimetryczną odpowiednio przeliczono i wyrażono liczbą ziaren pyłku $\mathrm{w} 1 \mathrm{~m}^{3}$ powietrza. $\mathrm{Z}$ przeprowadzonych badań wynika, że sezon pyłkowy Ambrosia rozpoczynał się o około miesiąc wcze- śniej i trwał dłużej we Lwowie niż w Lublinie. We Lwowie pyłek ambrozji rejestrowano od początku lipca, natomiast $\mathrm{W}$ Lublinie od drugiego tygodnia sierpnia. Sezon pyłkowy w obu miastach kończył się w różnych dniach października. Maksimum sezonowe w obu latach i sumy roczne w roku 2011 były znacznie wyższe w Lublinie niż we Lwowie. W obu miastach temperatura powietrza była najważniejszym czynnikiem meteorologicznym wpływającym na koncentracje pyłku. W czasie sezonu pyłkowego w Lublinie najczęściej wiał wiatr z NE i E, a we Lwowie $\mathrm{z} \mathrm{N}$ i SE.

Handling Editor: Bogusław Sawicki

This is an Open Access digital version of the article distributed under the terms of the Creative Commons Attribution 3.0 License (creativecommons.org/licenses/by/3.0/), which permits redistribution, commercial and non-commercial, provided that the article is properly cited.

CThe Author(s) 2013 Published by Polish Botanical Society 